
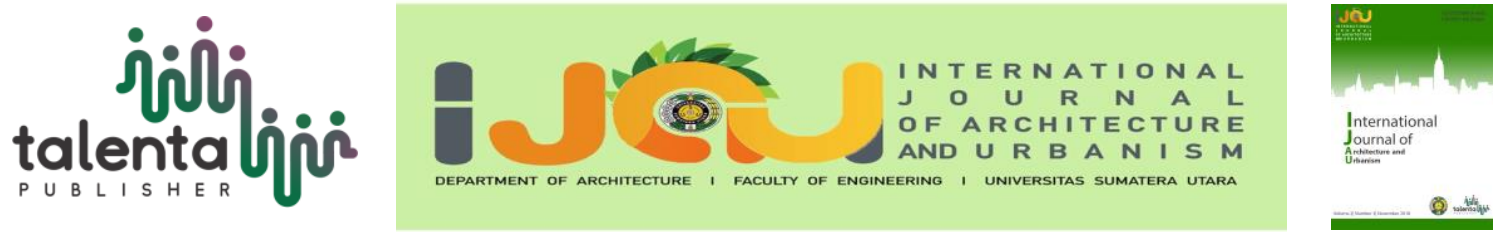

\title{
Development of Medan Labuhan Train Station
}

\author{
Indah Sekarini $^{1 *}$, Nelson M. Siahaan ${ }^{1}$ \\ ${ }^{1}$ Architecture Department, Faculty of Engineering, Universitas Sumatera Utara, Medan, Indonesia
}

\begin{abstract}
Development of the city center of Medan Labuhan area requires public infrastructure to support community needs activities. One of the most needs is a train station. A train station is an important part in a contemporary urban area for living, entertaining and working. Trains assessed can cope with transportation problems that occur between regions. With the above considerations, it is necessary to make efforts that can improve the condition of Medan Labuhan Train Station. The approach of a design of Medan Labuhan Station Development is the theme of Neo Vernacular Architecture so that it can be aligned with the old station and surrounding buildings and support conservation activities in Chinatown Medan Labuhan. Improvement can be done by the development of Labuhan Station is a passenger station that can accommodate all the required activities and provide services as much as possible, so that service users feel well served and support various activities center and sub-center services Medan City in the North located in Medan Labuhan The method of study there are two approaches to this approach, the observation method, and the literature method. Observation method is done with several times to survey to the location of design. While the literature method is done by collecting data, both secondary data and primary data.
\end{abstract}

Keyword: Architecture, development, neo vernacular, train station.

\section{Introduction}

Development of Medan Labuhan area directly requires public infrastructure as one of the main supporters of community activities. If the infrastructure can function properly, users can easily meet their needs. One of the most important public infrastructures is transportation. Transportation is defined as the activity of moving or transporting something from one place to another [1]. Transportation also determines how an area can compete and grow in today's global era. With the development of this area raises a need for mass public transportation, which is one of the systems in the ship by the government.

In Medan Labuhan Sub district there is Labuhan Station, which is aimed to transport the plantation products from Labuhan. This station had become a passenger station, along with the increasing of road transport and the decreasing of passenger's interest so currently the station, which is in Medan Belawan route no longer transport passengers, but only used for the railway

\footnotetext{
*Corresponding author at:Department of Architecture, Faculty of Engineering, Universitas Sumatera Utara, Jalan Perpustakaan Gedung J07, Medan 20155, Indonesia
}

E-mail address: indahsekarini96@gmail.com 
line of goods in Trains CPO (Crude Palm Oil), PKO (Palm Kernel Oil), latex (latex) latex, fuel and fertilizer. This station connects between North Medan and Medan City, so it has the potential and holds the role of North Medan which has regional and international service. With the above considerations, it is necessary to make efforts that can improve the condition of Medan Labuhan Train Station. Improvement can be done with the development of Labuhan Station is a passenger station that can accommodate all the required activities and provide services as much as possible, so that service users feel well served and support a variety of activities center and sub-center services Medan City in the North located in Medan Labuhan.

\section{Literature Review}

\section{Object Description}

The station is part of a railway that has an important role in providing services to rail service users. The station is a place to raise and lower passengers, where passengers can buy tickets, wait for trains and take care of their luggage [2]. The station is the end and beginning of the train journey, not the real destination or beginning of the journey. From the station still needed another mode of transportation to reach the final destination [3]. Development of Labuhan Railway Station is to increase a container or facility in the form of stations to accommodate the transfer of inter-mode of transportation from the use of road mode with the use of railway modes located in the area of Medan Chinatown Labuhan. So it can accommodate various activities both in Medan Labuhan and surrounding areas as a service center in the northern city of Medan.

\section{Location and Site}

The location of the design is on K.L. Yos Sudarso Street km. 12Kec. Medan Labuhan Kel. Pekan Labuhan.Relatively contour conditions. Accessible via K.L. Yos Sudarso Street with private vehicles and public transport. Through Potong Hewan Street $11.5 \mathrm{~km}$ travel time 20 minutes, via Cemara Street $16.3 \mathrm{~km}$ travel time 30 minutes. Through Tugu Kemerdekaan Street $24.7 \mathrm{~km}$ travel time 39 minutes, and through Balai Kota Street $18.3 \mathrm{~km}$ travel time 33 minutes. With the achievement to the location by train, from Medan Station 30 Minutes and from Belawan station 15 minutes (Figure 1). 


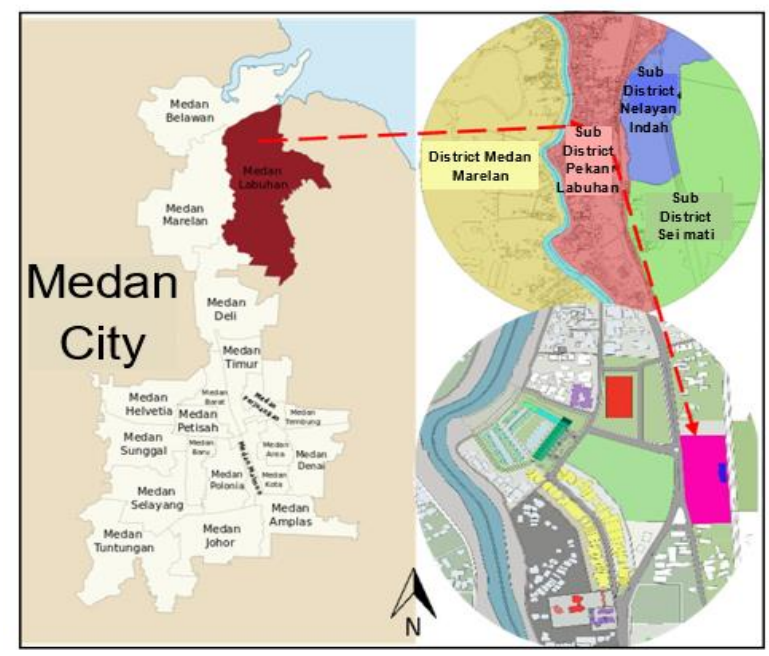

Figure 1. Maps of Location Site

\section{Theme Review}

Design of Development of Medan Labuhan Railway Station takes the theme of the architecture of neo vernacular in Colonial Art Deco style. The application of this theme is intended to unite new buildings with existing buildings and also to respect the old buildings so that buildings look together. The merger of this building can be seen from the window, which is a colonial characteristic with glass and circular shapes than in terms of ornaments and ornaments on the new roof in the adaptation of the model of the old building roof.

Almost all buildings that have Art Deco features use ornament as its identity. From the use of complex ornaments to simple and plastic basic shapes While the use of slight colors can be found in the processing of ornaments in the original buildings awake. Art Deco features can be found on the building facade. Similarly, the characteristics of the building facing the road, the symmetrical divider of the building. The use of elements, ornaments or processing of openings is very prominent. Processing of the vertical and horizontal plane dominates the common feature of the Art Deco building.

\section{Methodology}

Selection of design location based on the RTRW ${ }^{1}$ of Medan in $2010-2030$ and the RTBL ${ }^{2}$ of Chinatown Medan Labuhan Area. Based on the structure of the area described that the North Medan service center located in Medan Labuhan precisely in Chinatown Labuhan area which functioned as a center of services and trade activities, health care centers, transportations service centers, and industrial activities. There are two approaches to this approach, the observation method, and the literature method. Observation method is done with several times to survey to

\footnotetext{
${ }^{1}$ Rencana Tata Ruang Wilayah : Spatial Plans

${ }^{2}$ Rencana Tata Bangunan Wilayah : Environmental Building Plan
} 
the location of design. While the literature method is done by collecting data, both secondary data and primary data.

\section{Results and Discussion}

Site Analysis

Location Medan Labuhan Train Station located on Yos Sudarso Street, Medan-Labuhan SubDistrict, Pekan Labuhan Sumatera Utara. Precisely in the Area. This land belongs to the government, which is the development of a transportation service center that serves as a railway station based on RTRW ${ }^{1}$ Kota Medan 2010-2030 with the determination of $\mathrm{KDB}^{3}: 70 \%$, KLB ${ }^{4}$ : 2 - 4 Floor, $\mathrm{KDH}^{5}: 20 \%$, and $\mathrm{GSB}^{6}: 8,5 \mathrm{~m}$. The condition at the current design site is the railway station that is not functioning properly, which is surrounded by residential residents. The location is located on the edge of the main road YosSudarso and is in the middle of the settlement with a time of one hour from Medan city center using public transportation or private vehicle. According to $\mathrm{RTBL}^{2}$ the Chinatown area, the area is designated as the allocation of social facilities and public facilities of the planning area. In the analysis of land use, the circumstances surrounding the location surrounded the settlement of citizens and there is also an old market called by residents with crooked old markets, there are some schools and also places of worship.

\section{Topology Analysis}

At this time Medan Labuhan train station is a freight train station, which serves as a place for loading and unloading of goods. This station as an intermediate station, it is because of its position, which is between the terminal station, which is small. The position of the rail above the ground (elevated track). And the building position is parallel to the at Grade railway, the buildings and rails are aligned, the position of entry to the station building and the relatively high concourse.

\section{Theme Implementation Analysis}

The theme installation analysis on the design of Medan Labuhan Station Development is adjusted to the old station building and the usual building. By adjusting the facade of the existing building is expected to align the two buildings. So history. The old Labuhan Station is awake and supports the Chinatown area into the heritage are. The application of Neo Vernacular in the building, with the uniqueness of columns, windows, doors, and roof. Neo Vernacular architecture is applied with modern technology in the form of steel reinforcement on columns and beams, and on the door and window using aluminum and wood[4]. Colonial architecture is closely related in response to the direction of the sun so that the application of second skin

\footnotetext{
${ }^{3}$ Koefisien Dasar Bangunan : Building Coefficient

${ }^{4}$ Koefisien Lantai Bangunan : Coefficient of Building Floor

${ }^{5}$ Koefisien Dasar Hijau : Green Base Coefficient

${ }^{6}$ Garis Sempadan Bangunan : Building Border Line
} 
system to respond to sunlight from east and west direction then apply landscape design to suit the needs of open space and create an area where clearly illustrated the combination of old station buildings and new buildings. Use of environmentally friendly materials is thereby creating thermal comforts that conform to the standards required by users. And make use of natural daylight lighting from sunlight.

\section{Basic Concept}

The theme applied in this design is the Art Deco Colonial Architecture. Where the application is based on the building condition Labuhan Medan Station which, is identical with the colonial character. Implementation of this theme is intended to unite new buildings with existing buildings and also to honor the old building, which is the first station in Medan then turn the atmosphere on the front of the old building with a new building with open spaces where there is a pool that will reflect the historic old building. Around of the location, there are stairs that functioned as a place to sit for visitors.

\section{Zoning of Site}

Location of design with an area of $\pm 1.5 \mathrm{H}$ located onYos Sudarso Street km. $12 \mathrm{Kec}$. Medan Labuhan Kel. Pekan Labuhan with $8,5 \mathrm{~m}$ from the main road. The site is divided into several zoning that is the existing building, main building with $\pm 70 \%$ and open space $30 \%$ of the land (Figure 2).

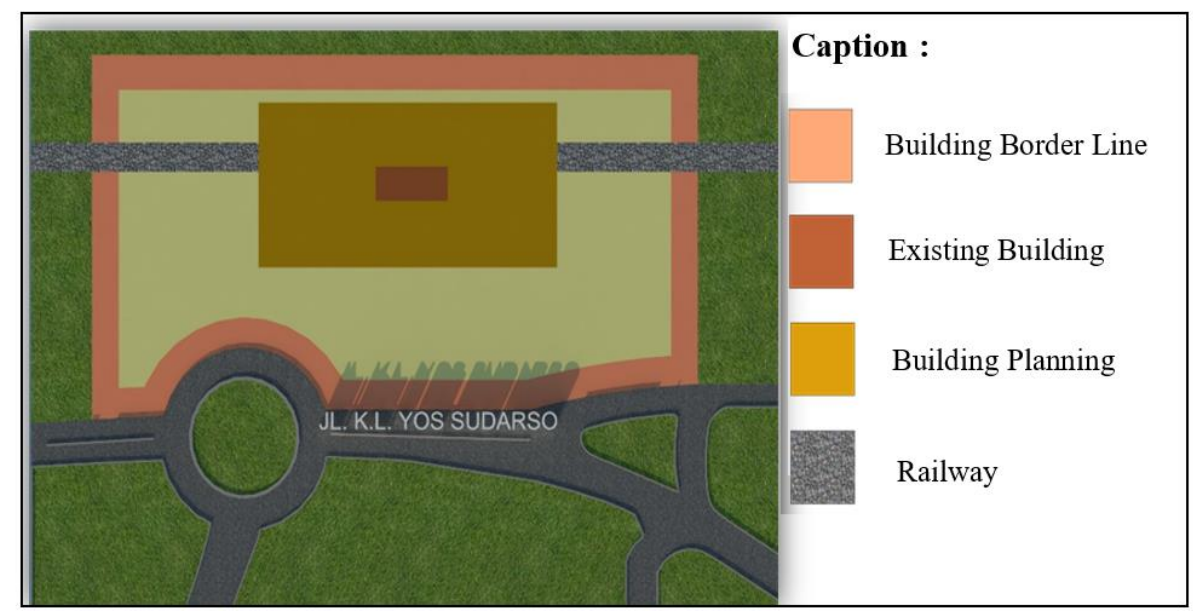

Figure 2. Zoning of site

\section{Outdoor Space}

A spatial arrangement on site-oriented site processing around the existing buildings and new buildings that function as a pool, parking area, and park. The parking area is divided into two that indoor and outdoor. For indoor parking is on the left of the building. For outdoor parking is on the right side of the building. At the entrance there are parks, drop off areas, pedestrian paths, and circulation in and out (Figure 3). 


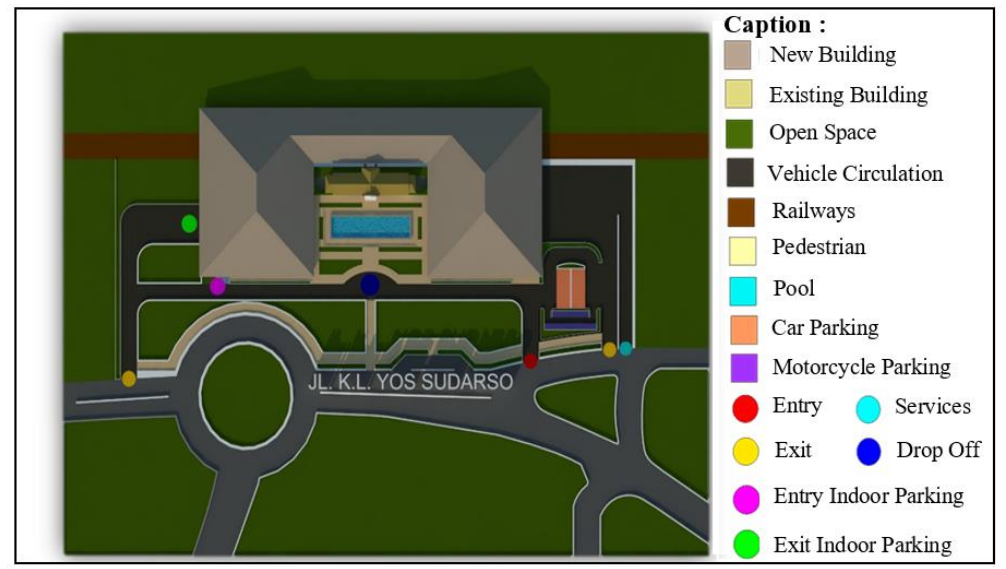

Figure 3. Outdoor space

\section{Mass Composition}

Form the mass around the old building to give the impression of a frame for the old building. For the station building, is a very necessary form of rectangular mass, because the train is a long-dimensional transport (Figure 4).

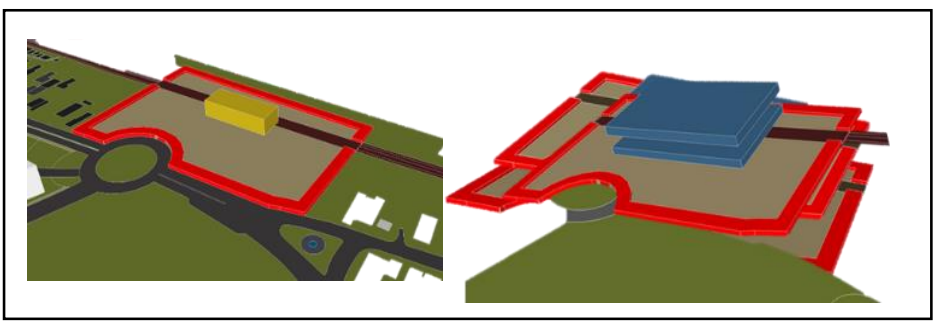

Figure 4. Mass composition concept

\section{Circulation of Achievement}

The designing tread has the main road located on Yos Sudarso Street. Vehicle circulation is only located at the front of Yos Sudarso Street. Circulation on the design site uses a one-way directional system. For the vehicle line, there is only one entrance, two exit lines and one service line then provided a drop off line to lower the passenger of private vehicles and public transport. On the design site, there are two parking zones. 1 zone inside the building precisely on the left side of the building. 1 zone is outside the building more in the parking lot parking taxi station(Figure 5).

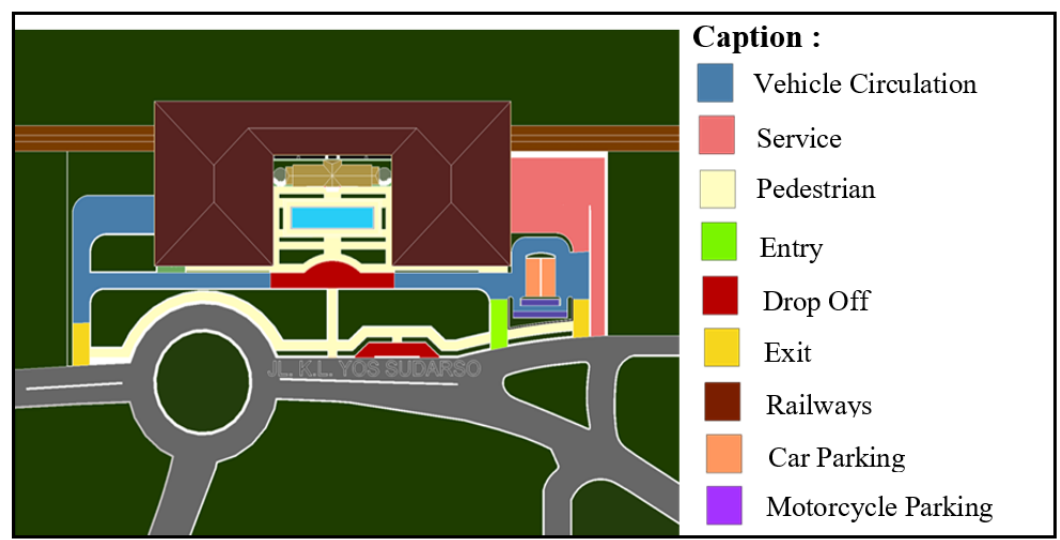

Figure 5. Circulation of achievement 


\section{Zoning of Building}

Site zoning consists of parking zones, common zones, private zones, service zones, vertical circulation zones of escalators and stairs, management zones and zone support facilities such as souvenir retail areas, food court outlets, mini markets, atm centers, nursing mothers' rooms, smoking rooms, and Islamic prayer room.

\section{Circulation of Building}

Development of Medan Labuhan Train Station uses two types of circulation, namely the horizontal and vertical circulation. Horizontal circulation in the form of corridors and vertical ladders and escalators.

\section{Structure of Design}

Development of Medan Labuhan Railway Station uses a rigid frame system, a system that supports the functions of spaces within it with a grid system. The grid on this building is $10 \mathrm{mx} 10 \mathrm{~m}$. Building using pile foundation with main column $80 \mathrm{~cm} \times 80 \mathrm{~cm}$. Dimensions of the main beam are $40 \mathrm{~cm} \times 80 \mathrm{~cm}$, and the beam is $20 \mathrm{~cm} \times 35 \mathrm{~cm}$. The building also implements a dilation system to strengthen the structure (Figure 6).

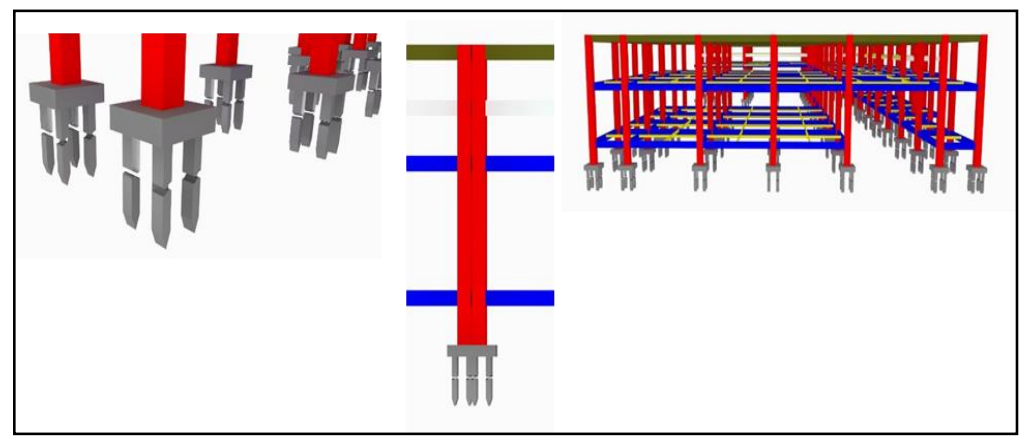

Figure 6. Structure of design

\section{Architecture Design}

Medan Labuhan Train Station is located at K. L. Yos Sudarso Street Km. 12 Kec. Medan Labuhan Kel. Pekan Labuhan. This railway station includes the main line on K.L. Yos Sudarso Street. This road is the main access to Medan Labuhan and Belawan Harbor (Figure 7).

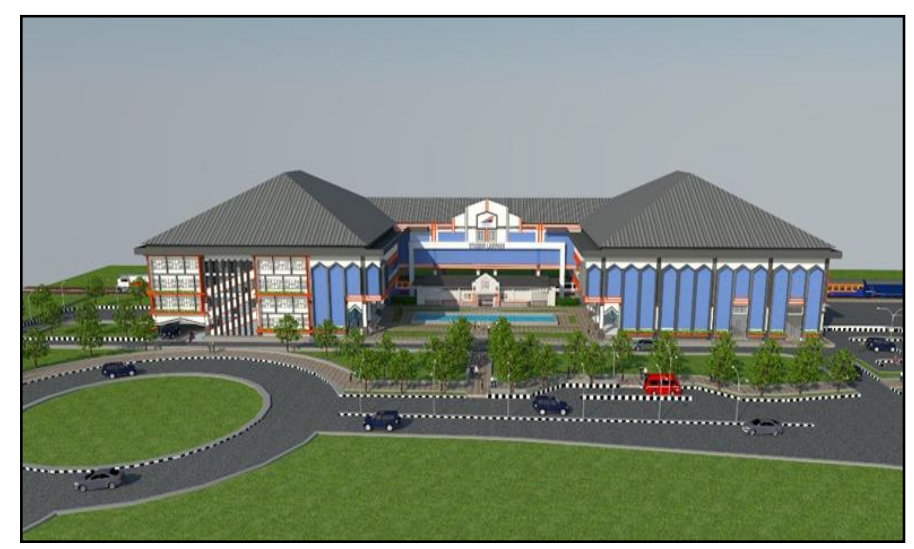

Figure 7.The view of Medan Labuhan Train Station 
Locations are located on arterial roads allowing for possible defects due to high road users in the area, thus minimizing existing congestion by separating the main entrance and outlet routes. The entry point is on the right of the site. Medan Labuhan Train Station consists of an old station building, which is then turned into a gallery located in the center of the building and new building as a transportation center that is easily reached via the main road located on the left and right side of the old building. Form the mass of Medan Labuhan Train Station requires a rectangular shape because the train is a long-dimensional transport and is supported by the formation of sites extending from south to north. On the left side of the station, there is the exit point the main station that is the exit point a drop off users and indoor parking. On the right side of the station, there is an exit point for outdoor parking users as well as service exits. On the right side of the station, there is also a proper service entry lane with an exit point. To reduce congestion due to public transportation that does not have a special stop location, Medan Labuhan Train Station provides a special place of public transportation stops so that the station users can easily access Medan Labuhan Train Station both with private vehicles and public transport. Public transport stops are integrated directly with the pedestrians on the Station.

The courtyard in the middle of the site aims to turn the atmosphere on the front of the old station building with a new station building with open space where there is a pool that will reflect the old building which enabled the gallery so that the historical value of the building is maintained. The courtyard is also a gathering point for all activities integrated with pedestrian tracks, drop off lines, museum visitors, station users (departure and arrival), introduction and pickup. On the left and right of the court as a supporter of services such as coffee shop, mini market, ATM center, and information center.

The parking area is divided into indoor and outdoor to make it easier for visitors. Indoor parking is on the left side of the building after the drop off area. Indoor parking has two main floors and two mezzanine floors which can be accessed using the existing ramp on the building. For the motorcycle is on the 1 st floor and the car is on the next three floors. There are two entry points between a motorbike and car. Motorcycles go straight into the motorcycle and motorcyclespecific parking lanes to the ramp track for parking on the next floor.

\section{Conclusion}

The development of Labuhan Railway Station is to improve the condition of Medan Labuhan Train Station to become a passenger station that can accommodate all the required activities and provide the maximum service possible, so that service users feel well served and support various central activities and service sub-center of Medan City in the Northern part of Medan Labuhan. Implementation of themes and concepts optimally expected to affect the positive impact for the service of a railway station. 
The location of the station on Yos Sudarso Street Km. 12, Medan Labuhan Sub-district of PekanLabuhan. Achievement towards the location is quite easily accessible by the people of Medan and surrounding areas. Accessible by public or private transportation. Within a land area of $\pm 1.5 \mathrm{Ha}$, the building can provide services and good facilities as a transportation center in the area of Pekan Labuhan.

Medan Labuhan Train Station is a very potential location to be developed into a metropolitan area; this is because the location of the site is too close to the Port of Belawan and is also a development area as a facility that must be realized in the area. Medan Labuhan Railway Station is designed with two floors and keeps the old station. Medan Labuhan Train Station is designed on site with planned road plans into arterial roads so that the intensity of activity at the Station will increase.

This Railway Station themed Neo Vernacular Architecture, which means a built environment in which it refers to the local language by taking the existing architectural elements into modern forms with the aim of preserving the local elements that have been empirically formed by a tradition without putting aside the values of local traditions. In this case, Medan Labuhan Train Station takes the theme of the art deco colonial architecture on its implementation concept, following a similar theme applied to the old station building so that the building looks aligned.

\section{Acknowledgment}

This research is an original work of researcher as a suggestion for government to overcome Transit Oriented Development (TOD) problems in Belawan, Medan-Indonesia.

\section{REFERENCES}

[1] E. K. Morlok, Introduction to transportation engineering and planning, New York: McGraw-Hill, 1978.

[2] I. Subarkah, Jalan kereta api, Idea Dharma, 1981.

[3] S. Warpani, Merencanakan sistem perangkutan, Bandung: ITB, 1990.

[4] D. Erdiono, Arsitektur 'Modern' (Neo) Vernakular di Indonesia, SABUA, 3(3), 2012. 